\title{
Market failure and government failure in European debt crisis
}

\author{
Jingwen Yan $^{1}$, Zhishan Cai ${ }^{1}$, and Rui Zhou ${ }^{1, *}$ \\ ${ }^{1}$ School of Economics, Wuhan University of Technology, Wuhan, China
}

\begin{abstract}
This paper takes the "five European pig countries" in the European debt crisis as an example to analyze the event from the perspective of market failure and government failure. The main conclusions are as follows: the European debt crisis is the common product of market failure and government failure. Both sides should make great efforts to solve this problem. There is a long-term process to solve the European debt problem. Only by developing competitive industries and regaining international competitiveness is the effective way for euro zone countries to get rid of the predicament fundamentally.
\end{abstract}

\section{Introduction}

The European sovereign debt crisis is the biggest and most profound crisis in recent years. The European debt crisis and the financial crisis have many things in common, all of which show a great impact on the liquidity of the financial market, and ultimately affect the overall financial stability and economic growth through the contagion of the financial market among different market varieties, different market participants and different countries. It is only more than ten years since human beings entered the 21 st century. The European debt crisis has been breaking out, transmitting, spreading and interweaving, forming a global sovereign debt crisis, causing severe shocks in the financial field just on the way from financial crisis to recovery, and the risk of global economic downturn has increased sharply [1]. Especially in the context of globalization, no country can be alone. To strengthen the research and prevention of sovereign debt crisis is an important issue to ensure sustainable economic development. In this case, the performance of market failure and government failure are outstanding. Next, we will analyze according to the requirements of the topic.

\section{Market failure and its causes}

\subsection{The inflow of capital is not converted into investment, and the labor participation rate is low}

Adam Smith's famous "invisible hand" theory said: "everyone tries to use his capital to maximize the value of his products. Generally speaking, he does not attempt to promote public welfare, nor is he clear about how much public welfare is promoted. What he pursues is only his personal well-being and personal interests. But when he does this, there will be a pair of invisible hands to guide him to achieve another goal, which is not what he pursues.
Because he pursues his personal interests, he often promotes social interests, which is more effective than when he really wants to promote social benefits. "However, the first sentence: "everyone tries to use his capital to maximize the value of his products." In some countries it is not satisfied.

For example, Greece, as a net importer of the euro area, accounted for $-9.13 \%$ of GDP in 2011, ranking first among the 12 countries in the euro area; meanwhile, Greece is also a net inflow country of capital [2].However, the inflow of capital has not been converted into investment, but mostly into consump-tion. Private consumption accounts for GDP. The proportion is as high as $76.15 \%$; before joining the euro area, the level of investment rate of Greece was maintained over $20 \%$, but after joining the euro area, the level of investment rate continued to decline, only $17.05 \%$ in 2010 , far lower than the level of about $20 \%$ of other countries, and the ability of economic development is low. And Portugal, which has long been an autocratic country, has carried out a series of liberalization reforms and gradually opened up foreign trade and investment in order to join the EU. But excessive dependence on consumption has led to a significant decline in competitiveness.

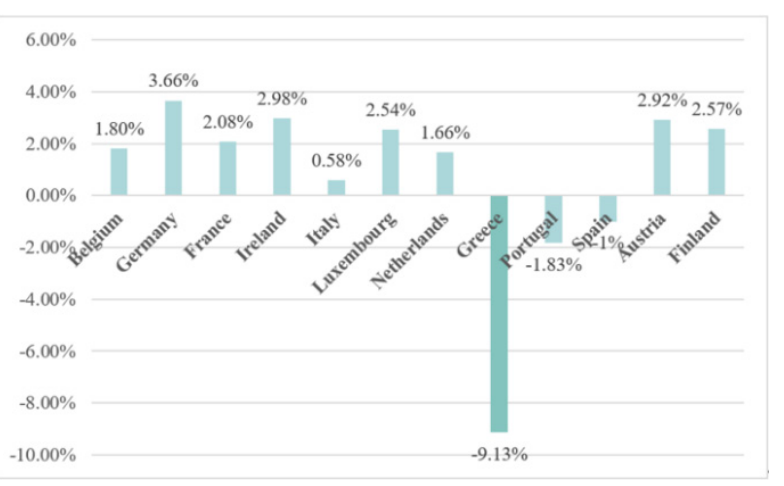

Fig. 1. Increasing rates of GDP of 12 countries in the euro area in 2011.

\footnotetext{
* Corresponding author: zhourui@whut.edu.cn
} 


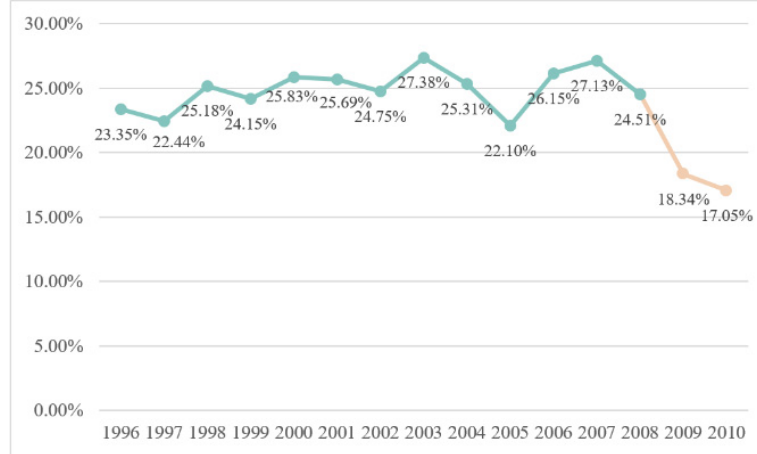

Fig. 2. Total investment as a share of GDP in Greece from 1996 to 2010.

The low labor participation rate in Greece is a historical problem. One of my former teachers once explained to us, half-jokingly, why Greece broke out first: "the Greeks are lazy. In other countries, they work eight hours a day. The Greeks only work four hours a day, they have to rest, they have to work. How can they not produce money to spend?" However, despite the low labor participation rate in Greece, living standards are still very high. Where does the money come from? Obviously, it is "borrowed" by means of financing, which is not a longterm plan, so to some extent, the lower cost of financing in the euro area has laid the groundwork for Greece debt crisis [3]. The same is true in Portugal, where labor productivity is low and unemployment has risen significantly since its accession to the euro zone, which has exacerbated the problem of low labor participation

In my opinion, the main goal of investment should be to promote the growth of the real economy and the development of the industry, rather than using the funds from lower cost financing for consumption. Because the multiplier effect of investment is much more obvious than consumption.

\subsection{Real estate bubble causes hidden danger}

Taking Ireland as an example, the real estate bubble has become a huge problem. After joining the euro zone, Ireland vigorously developed the real estate industry. From 2002 to 2007, Ireland real estate prices rose by nearly $200 \%$, and the bubble was serious. These financing mainly came from the inflow of foreign capital, which entered the Irish banking system in the form of short-term loans, resulting in a sharp increase in bank loans. The real estate bubble brings financial revenue to cover up the structural financial problems. Once the real estate bubble burst, the problems will follow. Moreover, Spain, after joining the euro zone, has also obtained a large amount of capital inflow with low interest rate. This part of capital has not flowed to the manufacturing industry, but to the real estate industry [4]. The real estate industry is developing rapidly, which has promoted the Spanish economy. According to the research of OECD Spain annual series reports, in order to support the further development of the real estate industry, on the one hand, the government has promulgated relevant land policies, so that almost all land in the country can be used for real estate development, on the other hand, it has introduced a large amount of credit funds into the real estate industry. With the support of the government, it is very easy for real estate enterprises and individuals to obtain credit. In fact, this is guaranteed by the government reputation, which makes the government become the last payer, laying the groundwork for the coming of the future crisis.

The financial industry and the real estate industry in the crisis countries are both over expanding, which encroach on the resources of the real economy and cause the crowding out effect on the real economy. First of all, financial institutions are crazy for profits, which makes the real estate industry and financial industry expand excessively. Because of the strong procyclicality of the financial industry and the real estate industry, the price of real estate and financial assets declines sharply, which damages a country ability to repay debts, and leads to financial turbulence and capital flight, forming a sovereign debt crisis. Secondly, the over development of financial derivatives and the financial development of real estate industry further accumulate systematic risks, such as the financial and moral risks of high debt operation of real estate enterprises, and the credit and operational risks of Bank land development loans. This makes the real estate no longer based on its use value, but on the rise of real estate price. It transforms the constructive investment into financial investment, which leads to the excessive and abnormal development of the real estate industry and the financial industry. It accumulates huge financial risks and the excessive expansion of the financial industry and the real estate industry in the crisis country, which encroaches on the resources of the real economy. The extrusion effect is caused. The market did not allocate its own resources reasonably, which led to the abnormal development of industry and market failure.

\subsection{Unreasonable economic structure}

In Greece, where consumption is the source of economic growth for a long time, the level of manufacturing industry is weak. The proportion of manufacturing industry is only $19.64 \%$. Agriculture account ts for a relatively high proportion. The main growth point of economy is shipping and tourism. The proportion of hotel and catering industry accounts for $8.23 \%$, which is far higher than that of other countries. Moreover, in the manufacturing industry, the main products are food and beverage, mineral products, basic metals and other primary products, with low economic added value. Therefore, after the outbreak of the financial crisis, the shipping and tourism industries suffered heavy losses, and the fiscal revenue grew slowly, while the proportion of public expenditure reached $7.26 \%$, far higher than the European average of $4 \%$, causing serious debt problems.

It can be seen that the market has not been able to make a good solution to its own structural problems and has not reached the Pareto optimal state. 


\subsection{Crisis countries and moral hazard faced by rescuers promote the formation of crisis}

There are moral risks in the unified monetary policy and decentralized fiscal policy model of the euro area. After a long-term fiscal policy of over expansion, member states can enjoy their own benefits and share their losses. The advantage of expansionary fiscal policy is to stimulate economic growth, while the disadvantage is that it will increase the debt burden of the government and lead to currency crisis in the long run. Although it is well known that the excessive expansion of fiscal policy will have a negative impact on the euro area and worsen the debt problem of the country, due to the shared losses of member countries, for the crisis countries, in the short term, the advantages outweigh the disadvantages. Finally, with the "free ride" mentality, the crisis countries all chose the expansionary fiscal policy, and finally induced the sovereign debt crisis.

This is a typical case of "externality". The free riding among governments and the invisible guarantee of individual governments to banks are all abnormal reactions of the market. It promoted the formation of the crisis.

\section{Government intervention}

\subsection{The Greek government uncooperative assis- tance to the Troika}

After the outbreak of the European debt crisis, the crisis countries represented by Greece have applied to the European Union for financial assistance plans. So far, the troika has implemented three rounds of assistance plans for Greece, namely: 1. On May 2, 2010, it provided 110 billion euros of first round assistance to the Greek government; 2. On February 21, 2012, it provided 130 billion euros of second round assistance to Greece; 3. On July 13, 2015, it provided 86 billion euros of third round assistance to Greece.

Of course, the aid is not given to the Greek government unconditionally. Each round of aid is accompanied by the EU harsh reform conditions, including reducing government spending, increasing taxes, reducing pensions to reduce the fiscal deficit. This made the Greek people accustomed to high welfare treatment break out several national strikes in a short period of time. However, the first round of rescue did not achieve substantial success. The interest rate of national debt continued to rise, asset prices fell sharply, and the macro-economy continued to decline. In the second and third round of aid, the requirements of the European Union are more stringent, which makes Greek people who have always enjoyed a comfortable life with high welfare have to face a more severe austerity link and bear a substantial reduction in social welfare such as salary, pension and pension. This has threatened the vital interests of the Greek people and undoubtedly intensified the contradictions between the government and the people. But in the third round, the Greek government really did not want to accept more stringent conditions, holding a referendum to veto the rescue, causing Greece to miss the best rescue opportunity, and the situation worsened.

The vacillation of the Greek government position on whether to accept international aid delayed the process of saving the crisis. The referendum it held was just an oath of attitude, and it had no practical use. Instead, this intervention had a negative impact and belonged to the government failure.

\subsection{The structure and organization of the euroz- one itself}

Economic policy includes fiscal policy and monetary policy. Due to the initial design problems of the euro area, there has been a long-term conflict between unified monetary policy and decentralized fiscal policy in the region. The monetary policy of euro area has been controlled by Germany, France and other countries for a long time. When Germany, France and other countries launch stable monetary policy with the goal of stabilizing prices, for the crisis countries with relatively high economic growth rate and inflation rate, it is a tighter monetary policy. Therefore, Greece and other crisis countries cannot adjust economic growth through monetary policy, but only through fiscal policy. It like a plane with only one wing, which can fly after all, making the road to economic recovery more difficult.

I think that the problems of the EU itself belong to the improper design of the government, the government intervention without positive impact on the economy, and the government failure.

\section{Correlation analysis of main economic indicators of six European countries}

\subsection{Correlation analysis of economic develop- ment levels}

This article will use GDP as an indicator of the level of economic development. According to the data analysis, the economic development levels among the six European countries are highly positively correlated. Among them, the correlation between the economic development level of Spain and France and Ireland is the most significant, and the correlation coefficient reaches 0.99 .

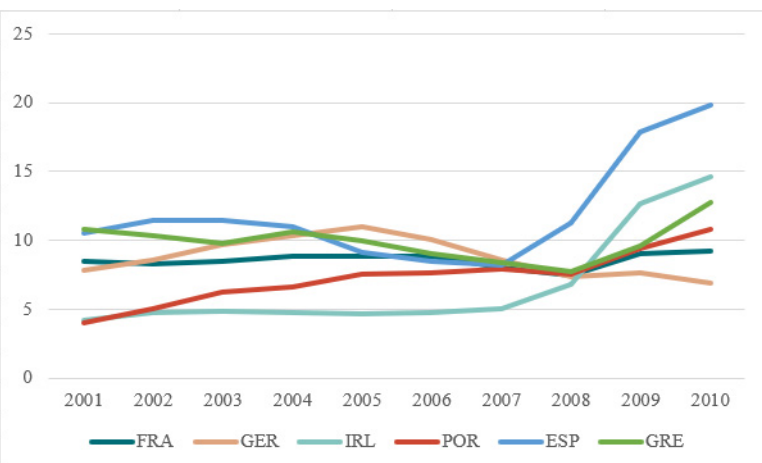

Fig. 3. Statistics on the economic development level of six European countries. 


\subsection{Correlation analysis of unemployment levels}

This article will use the unemployment rate as an indicator of the level of unemployment.It can be seen from the data analysis that there is a large difference in the correlation of unemployment levels among the six European countries. The unemployment level in Germany is mainly negatively correlated with other countries. Among them, Germany has a relatively large negative correlation with Ireland and Spain, and the correlation coefficients are 0.64 and -0.63 . The employment situation among other countries is mainly a positive change relationship. Among them, the unemployment level between Ireland and Spain has the highest positive correlation, with a correlation coefficient of 0.95 .

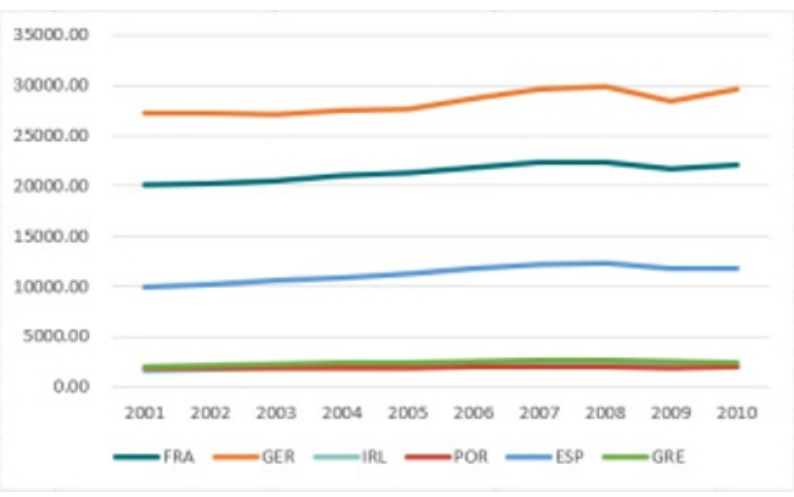

Fig. 4. Unemployment rate data for six European countries.

\subsection{Correlation analysis of price change levels}

This article will use the inflation index as an indicator of price changes.It can be seen from the data analysis that the price change levels among the six European countries are highly positively correlated. The correlation coefficients of inflation levels among countries have reached more than 0.95 .

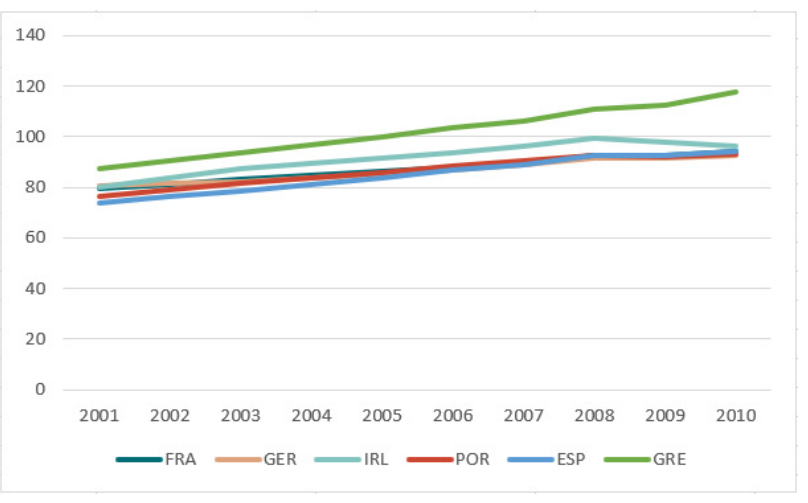

Fig. 5. Inflation rate data of six European countries.

Based on the above analysis, it can be seen that the six European countries have shown a high degree of correlation in economic development after joining the EU. The establishment of the EU makes the economies of the European Union highly integrated. Although this can ensure that the economies of the European Union have a certain degree of development, we should also see the risk integration brought about by economic integration [5]. It is particularly prominent in the European debt crisis.

\section{Conclusion}

The debt crisis in Europe is a complex and far-reaching problem, which requires the joint efforts of governments and correct strategies. Here are some suggestions.

- Maintaining the sustainability and rationality of sovereign debt: The main source of debt crisis is that the scale of debt has not been effectively controlled. To a large extent, it is because the government has not done a good job in planning and budgeting, borrowed debt blindly, and unconsciously exceeded its ability to repay. In addition, the scope of application of borrowed debt should be conducive to improving the ability to repay debt, such as developing production as much as possible, rather than blindly carrying out infrastructure construction, or borrowing new accounts for old ones, improving national welfare, etc.

- Strengthen the matching of macroeconomic policies: This is a challenge to the system itself of the eurozone, because if the system can not be changed, the aid plan can only maintain temporary stability, and can not fundamenttally eliminate the debt crisis. In view of the contradiction between monetary policy and fiscal policy mentioned above, governments of all countries should fully discuss this issue, and let other countries participate in the discussion when formulating their own fiscal policy, so as to finally promote the integration of fiscal policy.

- Strengthen supervision and control within the organi-zation: When the new Greek government announced the actual financial situation of the previous one, the world was shocked by the false financial figures of the previous one, which was obviously the failure of the regulators to fulfill their responsibilities. Greece was not qualified to enter the euro zone according to the conditions, but Goldman Sachs has made the corresponding financial qualification table for it, which makes Greece success-fully join the euro zone. There are many similar cases of lack of supervision, such as Italy long-term tax evasion, which contribute to the risk, strengthen supervision and the general trend.

\section{References}

1. C. Broto and G. Pérez-Quirós, "Disentangling contagion among sovereign CDS spreads during the European debt crisis," Journal of Empirical Finance, vol. 32, 2015.

2. D. Guerreiro, "Is the European debt crisis a mere balance of payments crisis?" Economic Modelling, vol. 44, 2014.

3. L. BocolaG. Bornstein and A. Dovis, "Quantitative sovereign default models and the European debt crisis," Journal of International Economics, vol. 118, 2019.

4. P. Reusens and C. Croux, "Sovereign credit rating determinants: A comparison before and after the European debt crisis," Journal of Banking and Finance, vol. 77, 2017. 
5. M. Gruppe and C. Lange, "Spain and the European sovereign debt crisis," European Journal of Political Economy, vol. 34, 2014. 